\title{
Clinical Characteristics of Asymptomatic Hepatitis B Virus Carriers with YMDD Mutant not Treated with Lamivudine
}

\author{
SATSUKI KOBAYASHI \\ Department of Medicine, Kurume University School of Medicine, \\ Kurume 830-0011, Japan
}

\begin{abstract}
Summary: We previously developed a method of detecting drug-resistant mutation of hepatitis $B$ virus (tyrosine (Y)-methionine (M)-aspartic acid (D)-aspartic acid (D) (YMDD) mutation) caused by the antiviral agent lamivudine. Using this method, we also reported that YMDD mutation is present in asymptomatic carriers that had not been administered antiviral agents. Thus, we investigated the clinical characteristics of 18 asymptomatic carriers of hepatitis $B$ virus by various biochemical and virological examinations, and compared the results between five subjects with YMDD mutation and 13 subjects without mutation. Although there was no significant difference in the results of various examinations between the two groups, the quantity of virus was generally small, and S-antigen disappeared in 2 patients in whom YMDD mutation was detected. These results suggest that there is no particular cause for the appearance of mutant viruses, but that they occur spontaneously as they gain fitness and, with a subsequent decrease in the absolute quantity of viruses, become relatively easy to detect.
\end{abstract}

Key words HBV carriers, mutation, YMDD, fitness, lamivudine

\section{INTRODUCTION}

Lamivudine was approved in Japan as an antiviral agent effective for the treatment of patients with chronic hepatitis B virus (HBV) infection. However, lamivudine induces lamivudine-resistant $\mathrm{HBV}$ in some patients on long-term administration. Lamivudine-resistant HBV has shown a few mutations in its genome [1]. We previously developed a simple method for detecting mutation of genes that code for the YMDD motif, which is one of the sites of the appearance of such mutations [2] and, using this method, reported the presence of YMDD mutations also in asymptomatic carriers (ASC) not treated with nucleotide analogues, such as lamivudine, or antiviral agents [3]. Thus, in this study, we evaluated why mutations were detected in the YMDD motif region, which is generally considered to be a highlyconserved region, in these untreated patients on the basis of the clinical background.

\section{PATIENTS AND METHODS}

The subjects were 18 ASC ( 8 males and 10 females encountered at the Second Department of Medicine, Kurume University) who have maintained a normal alanine aminotransferase (ALT) level for 1 year or longer. None of these subjects had a history of the use of antiviral agents, such as lamivudine or interferon.

\section{Biochemical examinations \\ HBsAg was detected by enzyme immunoassay (AxSYM, HBsAg; DAINABOT, Tokyo, Japan).}


$\mathrm{HBsAg}$ assay findings were expressed as $+(\mathrm{S} / \mathrm{N} \geqq$ 2.0) and $-(\mathrm{S} / \mathrm{N}<2.0)$.

$\mathrm{HBeAg}$ and anti-HBe antibody were detected by enzyme immunoassay (AxSYM, HBe, anti-HBe; DAINABOT). HBeAg assay findings were expressed as $+(\mathrm{S} / \mathrm{N}>5.0)$, $\pm(2.1<\mathrm{S} / \mathrm{N} \leqq 5.0)$, and $-(\mathrm{S} / \mathrm{N} \leqq$ 2.1). Anti-HBe antibody assay findings were expressed as $+(\%$ inhibition $>70 \%)$, $\pm(50<\%$ inhibition $\leqq 70)$, and $-(\%$ inhibition $\leqq 50 \%)$.

\section{$H B V$-DNA level}

The HBV DNA level was measured by the branched DNA probe assay (Chiron,CA,USA). The cut-off value of the assay was $0.7 \times 10^{6}$ equiv. (0.7 $\mathrm{Meq}) / \mathrm{ml}$.

\section{Extraction of $H B V-D N A$}

HBV-DNA was extracted from $100 \mu \mathrm{l}$ of serum sample using the nucleic acid extraction kit SMITEST EX-R\&D (Genome Science Laboratories, Fukushima, Japan).

\section{Analysis of YMDD mutation}

Mutation of the YMDD motif was analyzed using a SMITEST HBV-YMDD mutation detection kit (Genome Science Laboratories) [2].

Evaluation of precore (Pre-C) and core promoter (CP) mutations

Pre-C and CP mutations were evaluated using a SMITEST HBV Precore mutation detection kit and a SMITEST HBV core promoter mutation detection kit (Genome Science Laboratories), respectively [4].

\section{Evaluation of $H B V$ genotype}

The HBV genotype was evaluated using a SMITEST HBV genotype detection kit (Genome Science Laboratories) [5].

\section{RESULTS}

Characteristics of subjects, results of evaluation of YMDD motif mutations, and results of biochemical and virological tests (Table 1)

YMDD mutations were detected in 5 of the 18 subjects, and all mutations were mixed types with wild variants. All 5 subjects were positive for $\mathrm{HBe}$ antibody, and 4 of them were middle-aged people (40-59 years) or older. The HBV-DNA level was

TABLE 1.

Characteristics of the $18 \mathrm{ASC}$ and the results of biochemical and virological tests

\begin{tabular}{|c|c|c|c|c|c|c|c|c|c|}
\hline No. & Age & Sex & $\begin{array}{l}\text { Anino acid sequence } \\
\text { in YMDD motif }\end{array}$ & $\begin{array}{l}\mathrm{Hbe} \\
\mathrm{Ag} / \mathrm{Ab}\end{array}$ & $\begin{array}{l}\mathrm{AST} \\
(\mathrm{IU} / \mathrm{L})\end{array}$ & ALT & $\begin{array}{l}\text { HBV DNA } \\
(\mathrm{Meq} / \mathrm{ml})\end{array}$ & $\begin{array}{l}\text { PreC/CP } \\
\text { mutation }\end{array}$ & Genotype \\
\hline 1 & 19 & $\mathrm{~F}$ & YMDD & $+1-$ & 22 & 31 & 400 & Mix/Mix & $\mathrm{C}$ \\
\hline 2 & 22 & $\mathbf{M}$ & YMDD & $+1-$ & 21 & 20 & 500 & Wild/Wild & $\mathrm{C}$ \\
\hline 3 & 33 & M & YMDD & $+1-$ & 21 & 30 & 500 & n.t./n.t. & n.t \\
\hline 4 & 25 & $\mathrm{~F}$ & YMDD & $-1+$ & 19 & 10 & $<0.7$ & Wild/Mutant & $\mathrm{C}$ \\
\hline 5 & 25 & $\mathrm{~F}$ & YMDD & $-1+$ & 22 & 22 & $<0.7$ & Mix/Mutant & $\mathrm{C}$ \\
\hline 6 & 28 & $\mathrm{~F}$ & YMDD & $-1+$ & 21 & 18 & $<0.7$ & Mix/Wild & B \\
\hline 7 & 29 & $\mathrm{~F}$ & YMDD & $-1+$ & 17 & 11 & $<0.7$ & Mutant/Mutant & $\mathrm{C}$ \\
\hline 8 & 46 & $\mathrm{~F}$ & YMDD & $-1+$ & 19 & 9 & $<0.7$ & Mutant/n.d. & $\mathrm{C}$ \\
\hline 9 & 61 & $\mathrm{~F}$ & YMDD & $-1+$ & 20 & 24 & $<0.7$ & Mix/Mutant & $\mathrm{C}$ \\
\hline 10 & 49 & M & YMDD & $-1+$ & 21 & 20 & $<0.7$ & Mutant/n.d. & $\mathrm{C}$ \\
\hline 11 & 59 & M & YMDD & $-1+$ & 34 & 36 & $<0.7$ & Mix/Mutant & $\mathrm{C}$ \\
\hline 12 & 36 & M & YMDD & $-1+$ & 17 & 20 & $<0.7$ & n.d./n.d. & $\mathrm{C}$ \\
\hline 13 & 73 & M & YMDD & $-1+$ & 28 & 35 & 1.0 & Mutant/n.d. & $\mathrm{B}+\mathrm{C}$ \\
\hline 14 & 26 & $\mathrm{~F}$ & YMDD + YIDD & $-1+$ & 23 & 21 & $<0.7$ & Mutant/n.d. & $\mathrm{C}$ \\
\hline 15 & 49 & M & YMDD + YIDD & $-1+$ & 24 & 18 & $<0.7$ & n.d./n.d. & n.d. \\
\hline 16 & 57 & $\mathrm{~F}$ & YMDD + YIDD & $-1+$ & 20 & 15 & $<0.7$ & Mutant/Mutant & $\mathrm{C}$ \\
\hline 17 & 59 & $\mathrm{M}$ & YMDD + YVDD + YIDD & $-1+$ & 27 & 25 & $<0.7$ & Mutant/Wild & $\mathrm{C}$ \\
\hline 18 & 64 & M & YMDD + YVDD + YIDD & $-1+$ & 19 & 16 & $<0.7$ & n.d./n.d. & $\mathrm{C}$ \\
\hline
\end{tabular}

n.t.: not test; n.d.: not detect 
TABLE 2

\begin{tabular}{lccc}
\multicolumn{4}{c}{ Comparison between YMDD mutant $(-)$ and YMDD mutant $(+)$ groups } \\
\hline & YMDD mutant $(-)$ & YMDD mutant $(+)$ & P Value \\
\hline Age & $39.7 \pm 17.7$ & $51.0 \pm 15.5$ & 0.5221 \\
Sex (M/F) & $6 / 7$ & $3 / 2$ & $>0.9999$ \\
AST(IU/L) & $21.8 \pm 4.7$ & $22.6 \pm 3.2$ & 0.4263 \\
ALT(IU/L) & $23.3 \pm 8.5$ & $19.0 \pm 4.1$ & 0.2669 \\
$\gamma$-globulin(\%) & $18.9 \pm 3.8$ & $19.6 \pm 4.0$ & 0.7518 \\
eAg Positive & $3 / 13$ & $0 / 5$ & 0.5089 \\
HBc Ab 200X $(\%)$ & $91.2 \pm 10.2$ & $72.4 \pm 22.8$ & 0.0582 \\
HBs Antigen negative & $0 / 13$ & $2 / 5$ & 0.0654 \\
HBV DNA $(<0.7 \mathrm{Meq} / \mathrm{ml})$ & $9 / 13$ & $5 / 5$ & 0.2280 \\
\hline
\end{tabular}

very low in most subjects. As for Pre-C/CP mutations, Pre-C mutation was noted in 3 of the 5 subjects with YMDD mutations. All subjects in which YMDD mutation was detected were positive for $\mathrm{HBe}$ antibody, and the HBV genotype was type $\mathrm{C}$ in all 4 subjects in whom the genotype could be determined.

Comparisons between the YMDD mutant (+) group and YMDD mutant (-) group

Table 2 compares the results of various tests between the group in which YMDD mutations were detected and those in whom it was not detected. Concerning the age, gender, aspartate aminotransferase (AST), ALT, history of AST or ALT elevation, and $\gamma$-globulin level, the mean age was slightly higher in the YMDD mutation (+) group, but there was no significant difference noted in the other parameters. As for virological factors, none showed a significant difference except that the $\mathrm{HBc}$ antibody level was slightly lower in the YMDD mutation $(+)$ group. Furthermore, HBs antigen became negative in 2 subjects (No.15 and 18) of the YMDD mutation $(+)$ group.

\section{DISCUSSION}

Since there was no significant difference observed in the results of various tests between the YMDD mutation $(+)$ group and mutation $(-)$ group, the possibility that mutant viruses appeared due to a particular cause was suggested to be small. Thus, if YMDD mutations are assumed to have occurred spontaneously regardless of the use of antiviral agents, changes in "viral quasispecies" may be related to the detection of YMDD mutant viruses even in untreated patients. In a review of RNA viruses, a parameter that represents the degree of adaptation of a virus to its biological environment is called fitness [6]. HBV is a DNA virus that produces pregenome RNA in the replication process. Therefore, HBV gains fitness after infection similarly to RNA viruses, and viruses with mutations in various regions (e.g. Pre- $\mathrm{C} / \mathrm{CP}$, polymerase region, and PreS region) are produced spontaneously. However, mutants that can survive and replicate consistently in the host environment over a long period gradually become the majority, resulting in changes in the composition of the viral population. YMDD mutant viruses are, thus, considered to have become more detectable among viruses that have developed mutations in the polymerase region. This hypothesis is also considered to apply to YMDD mutations detected in association with lamivudine administration, and reasonably explains the mechanism involved in the appearance of mutant viruses [7]. The hypothesis suggesting "spontaneous occurrence of YMDD mutant viruses" is supported by the report that interval until the appearance of YMDD mutants is detected in lamivudine-treated patients differs, i.e. mutations are detected very early in some cases [8].

Such subtle changes in the population of mutant virus groups may also be related to the disappearance of HBs antigen. The disappearance of HBs antigen itself is considered to be naturally associated with a decrease in the virus level, but similarly to the appearance of YMDD mutants, various mutations that have occurred as the virus has been exposed to immunological pressure from the host over a prolonged period may involve the gene that codes for the epitope region of the HBs antigen $[9,10]$.

There are still few reports of YMDD mutants of HBV being detected in patients who were not treated with antiviral agents such as lamivudine [11,12]. However, as tyrosine (Y)-Valine (V)-aspartic acid (D)-aspartic acid (D) (YVDD) or tyrosine (Y)isoleucine (I)-aspartic acid (D)-aspartic acid (D) 
(YIDD) type viruses have been reported to comprise the majority of retroviruses such as murine leukemia virus (MLV) and human endogenous retrovirus $\mathrm{K}$, the spontaneous development of YMDD mutant HBV does not appear to be unreasonable [13,14]. Interestingly, both wild-type MLV (YVDD-type) and mutant-type MLV (YMDD-type) have been reported to be resistant to lamivudine [15].

As the sensitivity of detecting of mutants improves in the future, reports of the detection of presently undetected YMDD mutant viruses that comprise the minority of the virus group are expected to appear. Detection of such mutants is anticipated as it is considered to be effective for predicting YMDD mutations that occur in association with lamivudine administration.

ACKNOWLEDGMENTS: The auther thanks Prof. Michio Sata, Dr. Tatsuya Ide, and Dr. Kei Ogata (Department of Medicine) for their invaluable advice and technical support.

\section{REFERENCES}

1. Tipples GA, Ma MM, Fischer KP, Bain VG, Kneteman NM et al. Mutation in HBV RNA-dependent DNA polymerase confers resistance to lamivudine in vivo. Hepatology 1996; 24:714-717.

2. Kobayashi S, Shimada K, Suzuki H, Tanikawa K, and Sata M. Development of a new method for detecting a mutation in the gene encoding hepatitis $\mathrm{B}$ virus reverse transcriptase active site (YMDD motif). Hepatology Research 2000; 17:31-42.

3. Kobayashi S, Ide T, and Sata M. Detection of YMDD motif mutation in some lamivudine-untreated asymptomatic hepatitis B virus carriers. Journal of Hepatology 2001; 34:584-586.

4. Aritomi T, Yatsuhashi H, Fujino T, Yamasaki K, Inoue $\mathrm{O}$ et al. Association of mutation in the core promoter and precore region of hepatitis virus with fulminant and severe acute hepatitis in japan. Journal of Gastroenterology and Hepatology 1998; 13:1125-1132.
5. Okamoto H, Tsuda F, Sakugawa H, Sastrosoewignjo RI, Imai $\mathbf{M}$ et al. Typing hepatitis $\mathrm{B}$ virus by homology in nucleotide sequence: comparison of surface antigen subtypes. Journal of General Virology 1988; 69:2575- 2583.

6. Domingo E, Menendez-Arias L, and Holland JJ. RNA virus fitness. Reviews in Medical Virology 1997; 7:8796.

7. Gaillard RK, Barnard J, Lopez V, Hodges P, Bourne E et al. Kinetic analysis of wild-type and YMDD mutant hepatitis $\mathrm{B}$ virus polymerases and effects of deoxyribonucleotide concentrations on polymerase activity. Antimicrobial Agents and Chemotherapy 2002; 46:10051013.

8. Paik YH, Chung HY, Ryu WS, Lee KS, Lee JS et al. Emergence of YMDD motif mutant of hepatitis B virus during short-term lamivudine therapy in South Korea. Journal of Hepatology 2001; 35:92-98.

9. Kato J, Hasegawa K, Torii N, Yamauchi K, and Hayashi N. A molecular analysis of viral persistence in surface antigen-negative chronic hepatitis B. Hepatology 1996; 23:389-395.

10. Chen WN, and Oon CJ. Human hepatitis B virus mutants: significance of molecular changes. FEBS Letters 1999; 453:237-242.

11. Günther S, Sommer G, Plikat U, Iwanska A, WainHobson $S$ et al. Naturally occurring hepatitis B virus genomes bearing the hallmarks of retroviral $\mathrm{G}>\mathrm{A}$ hypermutation. Virology 1997; 235:104-108.

12. Kirishima T, Okanoue T, Daimon Y, Itoh Y, Nakamura $\mathrm{H}$ et al. Detection of YMDD mutant using a novel sensitive method in chronic liver disease type B patients before and during lamivudine treatment. Journal of Hepatology 2002; 37:259-265.

13. Poch O, Sauvaget I, Delarue $M$, and Tordo N. Identification of four conserved motifs among the RNAdependent polymerase encoding elements. The EMBO Journal 1989; 8:3867-3874.

14. Powell SK, Artlip M, Kaloss M, Brazinski S, Lyons R et al. Efficacy of antiretroviral agents against murine replication-competent retrovirus infection in human cells. Journal of Virology 1999; 73:8813-8816.

15. Halvas EK, Svarovskaia ES, Freed EO, and Pathak VK. Wild-type and YMDD mutant murine leukemia virus reverse transcriptases are resistant to 2', 3'-dideoxy-3'thiacytidine. Journal of Virology 2000; 74:6669-6674. 